\title{
"I ALWAYS KNEW IT... DIGO, QUIZÁS NO ERA PERFECT": TRANSNATIONAL ACTS OF IDENTITY' IN THE SPEECH OF A RETURNEE MIGRANT
}

\section{"I ALWAYS KNEW IT... DIGO, QUIZÁS NO ERA PERFECT": ATOS TRANSNACIONAIS IDENTITÁRIAS² NA FALA DE UM MIGRANTE RETORNADO}

\section{Katherine Morales*}

\section{ABSTRACT}

The following paper addresses the topic of transnationalism in U.S. territory Puerto Rico. As a previous Spanish colony and current U.S. territory, Puerto Rico provides rich ground for the study of fluid identities. While transnationalist literature has typically focused on describing contexts of crossed "borders" or cultures in a geo-political sense (cf. KRAMSCH and WHITESIDE, 2008; LI AND ZHU, 2013), Puerto Ricans have often been excluded from transnationalist discourses of Latin American communities due to their unique status as U.S. citizens. Through this article I aim to provide an ideological account of the complex voices and identities that make up the language practices of the Puerto Rican transnational. I adopt Jorge Duany's (2003) argument for Puerto Rican transnationalism on the basis of a shared sense of "cultural nationalism" as evidenced in the cultural and linguistic practices of a Puerto Rican returnee migrant. This migrant's linguistic practices and identity constructions are observed in relation to Michael Silverstein's (2003) socioindexicality. Coupling this frame with an ethnographic methodology allows the dynamic ways in which a transnational identity is constructed to become apparent, in real-time and in illuminated detail

Keywords: transnationalism; colonialism; language and identity; stylistic variation, indexicality.

\section{RESUMO}

$\mathrm{O}$ artigo a seguir aborda o tema de transnacionalismo no território estadunidense de Porto Rico. Como uma colônia espanhola antes de virar território dos EUA, Porto Rico oferece um campo rico para o estudo de identidades fluidas. Embora a literatura transnacionalista tenha tipicamente focado em descrever contextos de "fronteiras" cruzadas ou culturas em um sentido geopolítico (cf. KRAMSCH e WHITESIDE, 2008; LI E ZHU, 2013), os portoriquenhos foram frequentemente excluídos dos discursos transnacionalistas da América Latina devido ao seu status único como cidadãos americanos. Através deste artigo, pretendo fornecer uma explicação ideológica das vozes e identidades complexas que compõem as

\footnotetext{
* Trinity College Dublin, Ireland. moralesk@tcd.ie

1. The title for this paper is inspired by Le Page, Le Page, Tabouret-Keller (1985) groundbreaking study of identity and multilingual practices in Caribbean islands of Belize and St. Lucia.

2. The title for this paper is inspired by Le Page, Le Page, Tabouret-Keller (1985) groundbreaking study of identity and multilingual practices in Caribbean islands of Belize and St. Lucia.
} 
práticas linguísticas do transnacionalismo porto-riquenho. Adoto o argumento de Jorge Duany (2003) em relação ao transnacionalismo porto-riquenho com base em um sentimento de "nacionalismo cultural", como evidenciado nas práticas culturais e lingüísticas de uma migrante porto-riquenho. As práticas lingüísticas e as construções de identidade desse migrante são observadas em relação à socio-sexualidade de Michael Silverstein (2003). Unir esse quadro a uma metodologia etnográfica permite identificar as formas dinâmicas pelas quais uma identidade transnacional se constroi, em tempo real e com detalhes.

Palavras:chave: transnacionalismo; colonialismo; linguagem e identidade; variação estilística indexação.

\section{INTRODUCTION}

This paper addresses the issue of transnationalism in Puerto Rico, an unincorporated territory of the United States of America (hereafter USA). Puerto Rico has a population of 3.2 million citizens. While native Spanish speakers, they are simultaneously classified as U.S. citizens (US CENSUS BUREAU, 2018). Despite this official U.S. designation, the right of Puerto Ricans to claim American identity has been a source of controversy, with U.S. citizens in particular questioning the validity of a Spanish speaking 51 st state (BURNETT, DUFF, \& MARSHALL, 2001). Academics also argue that Puerto Rico's cultural inclinations are more similar to Peninsular Spain and neighboring Latin American and Caribbean countries than mainland American culture (ROCA \& LIPSKI, 2011). In many ways, this collective sense of Hispanic identity could make the Puerto Rican experience a transnational one, since tangible cultural and spatial boundaries are crossed when Puerto Ricans arrive in mainland U.S.A (DUANY, 2003). However, due to their unique status as U.S. citizens, these narratives are largely excluded from mainstream scholarship on transnationalism (MELÉNDEZ, 2015). This paper seeks to correct this exclusion, by presenting the case for the Puerto Rican transnational experience. The argument for inclusion within a transnationalism framework is based on a reading of indexical Spaces (cf. BLOMMAERT, 2007). Specifically, I examine the cultural and linguistic practices tied to these Spaces (context, people, interactions), demonstrating how they are navigated by islanders in order to make sense of their social worlds and their positionings therein.

\section{TRANSNATIONALISM}

The quality of being 'transcendent' is not new. It shaped the lives of our ancestors, played a pivotal role during colonialism, and continues to do so in 
modern society. Population movement is inspired by a series of factors, ranging from individuals seeking employment or educational opportunities to those escaping dictatorships, violence, inequality, and poverty (DUFF, 2015). By engaging with the circumstances of $19^{\text {th }}$ century immigrants, we find common ground between the immigrants of then and the transmigrants of today, particularly when it comes to the preservation of heritage culture:

"Many earlier migrants were, in some sense, transmigrants who remained in communication with their home country and participated in its national movement" (BASCH, ET AL., 1992: 9).

Yet, over the last decades, the subject of mobility and migration has garnered increasing attention, particularly due to rapid urbanization and the unprecedented rate at which population demographics are shifting (VERVOTEC, 2007). Additionally, new ways of communicating have transformed the rate at which ideas and practices are exchanged, such that one may experience another's culture virtually, as well as partake in preservation efforts of heritage and culture from one's own home (cf. PENNYCOOK, 2006). In applied linguistics, definitions of transnationalism have privileged the physical over the virtual and the frontiers of nation-state over other more amorphous borders, as demonstrated in Patricia Duff's (2015) definition of transnationalism as "the movement across cultural, linguistic, and (often) geopolitical or regional borders and boundaries of all types but especially those of nation-states" (DUFF, 2015: 57). Under this definition, a transnational is a person who has experienced dual or multiple senses of selves on account of their nomadic lifestyle or movement across geopolitically recognized nations. An etymological reading of the term 'transnationalism' provides an immediate sense of the ideological limitations that underpin this subject area. The morphological prefix 'trans-' indicates the quality of being transcendent or beyond, while subject 'national' involves the construct of a socio-politically recognized community of people united by shared spaces, histories, and cultures (OXFORD DICTIONARIES 2018). By deconstructing its morphological components, transnationalism as a sociological unit of inquiry sounds intimately related to other existing terms in sociolinguistics used to describe the impact of increased mobility and the exchange of goods through growing global economies and developing technologies - for instance, terms like superdiversity (VERVOTEC, 2007) and globalization (BLOMMAERT, 2010). Despite its global significance and academic usage in the context of the U.S. and the Americas (BRIGGS, MCCORMICK, and WAY, 2008), transnationalism excludes the experiences of historically exceptional cases, such as Guam and Puerto Rico. Its reliance on ideologically problematic 
constructs like 'nation' and one-to-one correlated sociocultural practices are also problematic, flattening migrant experiences in a mode akin to the narrow application of the term 'gender' to just a binary of practices. (ECKERT \& MCCONELLGINET, 1992). This is not to say, however, that the ideological foundations of transnationalism make it any less relevant as a social construct of practice. Rather, if we are to pursue a contemporary sociolinguistic analysis of fluid transcendent ways of being, we should re-conceptualize social identities such as 'transnational' (and the practices attached to them) as fluid ideological constructs that one either takes up or rejects, and negotiates dialogically in interaction. In essence, I follow Briggs, Mccormick, and Way's (2008) argument that "nation, like sex, is a thing contested, interrupted, and always shot through with contradiction" (p. 627) I take Puerto Rico to exemplify the issues around the use of fixed constructs such as 'nation' within discussions of transnationalism. I also show how the labelling of 'nation' and nationcultural-practices is, in reality, fluid, complicated, and discursively negotiated in a multiplex field of indexical meanings.

\section{THE PUERTO RICAN TRANSNATIONAL}

Population movement has formed an integral part of Puerto Rican postcolonial (post-Spain) history. It continues to do so today, with 5.1 million people of Puerto Rican descent residing in mainland U.S.A: a significantly larger number than those of Puerto Rican descent on the island (US CENSUS BUREAU, 2018). 1.5 million of this U.S. based Puerto Rican population are "island-born" Puerto Ricans. Puerto Rico's population is projected to decline even further in the next 30 years, due to a rise in unemployment and ongoing economic crisis (PEW RESEARCH CENTER, 2017).

While there is a long history of migration to and settlement in mainland United States, many scholars of migration focus on describing the journeys of unproblematically defined nation-states (cf. BASCH, GLICK SCHILLER, AND BLANC, 1994; LEVITT and JAWORSKY, 2007). Puerto Rico's status as an unincorporated U.S. territory, together with Puerto Ricans' U.S. citizenship "make some scholars reluctant to consider this experience as transnational" (MELÉNDEZ, 2015: 15). DeSipio and Pantoja (2007) have argued elsewhere that the exclusion of Puerto Ricans is to do with the "ease of migration" and their "quick access to vote" upon mainland residency (p. 104). Combined, these factors ultimately contribute to a perception of the Puerto Rican as "belonging" and "legal" and, therefore, immune to the struggles of other transnational groups. By consequence, "their 
process of $[\ldots]$ adaptation to civic and political life in the United States" is underresearched, creating large gaps in the study of Puerto Rican diaspora (DESIPIO and PANTOJA, 2007: 104).

Anthropologist Jorge Duany (2003) has argued for the inclusion of the Puerto Rican migrant on the basis of cultural identities, stating that "Puerto Rican migrants cross significant geographic, cultural, and linguistic borders between the Island and the mainland, and this displacement helps to reconfigure their national identities" (DUANY, 2003: 426). Linguistically, Puerto Ricans - like other Latinos - must come to terms with bilingualism and adopting English as a second language in order to "survive in a hostile U.S. environment" (MACHADO-CASAS, 2012). Island linguist Alicia Pousada describes fostering English as "linked in the minds of many Puerto Ricans with assimilationism, while defending Spanish as the hallmark of nationalism [...] despite the role of English as a language of wider communication on a global scale." (POUSADA, 1999). Those who possess cultural and political influence on the island, the Puerto Rican intelligentsia, add to the discourses of distinction and difference in relation to the United States (POUSADA, 1999). From a policy perspective, government institutions are expected to operate bilingually in Spanish and English. In practice, however, most function in dominant $S_{\text {Spanish }}^{3}$ or adopt translanguaging practices (cf. MAZAK \& CARROLL, 2016). In turn, public school education has changed direction in prescribing the language of instruction, choosing from 1950 to designate Spanish rather than English as the language of instruction. Socially, the island engages in international displays of Hispanic nationhood. For instance, when it comes to global competitions, such as the Olympics or Miss Universe pageants, the island independently enrolls as its own representation (DUANY, 2003). However, despite different linguistic and cultural practices, only a minority of islanders support the belief that Puerto Rico should be an independent country. Consequently, DUANY has concluded that "cultural nationalism is the dominant ideology of the Commonwealth government, the intellectual elite, and numerous cultural institutions on the Island as well as in the diaspora" whilst political nationalism is not (DUANY, 2003: 5).

This paper adopts the argument of colonial transnational on the basis of such evidence of Puerto Rican cultural nationalism. Further, it traces the perpetuation of ideologies and practices tied to this nationalism through the testimony of Miguel, a Puerto Rican returnee migrant, who performs norms of appropriacy and positions himself in various favorable ways in order to construct an identity that is both Puerto Rican and American.

3. Although the language norm of the federal court is notoriously English. 


\section{IDENTITIES AND SOCIAL MEANING IN SPEECH}

Identity-based research has played an increasingly important role in contemporary language research. In identity-based sociolinguistics research, an individual's daily practices, beliefs, values, and social affiliations are at the forefront of analysis. This is premised on the notion that an individual is never solely the result of their inherited social circumstances (e.g. place of birth). Rather, they are seen as having autonomy and agency in the interpretation of their actions. Studies conducted under this framework provide a more biographical account of language, capturing speech acts that arise with identity relations, being involved in certain social communities, and language attitudes.

The latest approach to language analysis builds on this notion of identity by shifting the focus from the individual and group to the language itself, particularly the question(s): "what am I accomplishing by engaging in this speech?", "what does it mean to speak this way or use this particular word/syntactic structure/accent in society?", moreover, "why does he/she speak like that?", "what does that say about them?" Crucially, meaning-based approaches to language increasingly consider ideologies of language. These are also referred to as metapragmatic knowledge or "ideologies articulating cultural valorizations" (SILVERSTEIN, 2003: 195) and they are concerned with language use in interaction. This shift of focus from speaker to language allows us to understand human beings as more than the sum of the groups they engage in, or the places that they have lived. Rather, they are perceived as humans that are capable of making use of different speech styles in "purposeful processes of meaning-making" (TAGG, 2016: 61).

Different orders of indexicality (SILVERSTEIN, 2003) come into view when adopting particular language styles in particular contexts. Different interactional contexts trigger different meanings and norms of appropriacy in a dialogic process that Silverstein denotes as presupposition, which builds on contextual competence or pragmatics of a conversation. The latter piece he calls entailment or a new communicative instantiation built on presupposition and intersubjectively constructed. The relationship between these two is not linear, rather continuously informed by a third element which he calls metapragmatics, or the ideologies of language which are hierarchically structured. The model is additive, such that meaning of language builds on previous meanings, but is also open to new intersubjectively created ones. In this way, Silverstein addresses discussions of the macro-micro relations in language and conceptualizes language as a dynamic and living phenomenon, as something that we do - an action - a behavioral or communicative act that does not exist in a theoretical vacuum. 
Metapragmatic discourses in mainland United States have historically promoted a "nationalistic" image that involves monolingual hegemony, or the idea that English is the language that "express[es] the spirit of [the] nation and the territory it occupies" (GAL, 2006: 163). Consequently, transnational Latinos communicating in accented English, or engaging in code-mixing practices, are prone to covert or overt linguistic discrimination, as they are deemed to diverge from the idealized standard (see ROSAS, 2016). On the island of Puerto Rico, the act of code-mixing generates different indexical values or valorizations: English use suggests the role of the outsider language, functions as a sign of prestige, and can be interpreted as an act of snobbery (PEREZ CASAS, 2008). Among Puerto Rican youth, it is believed to generate qualities of 'coolness' or trendiness - particularly in Netspeak (MORALES, forthcoming). It may also play a role in constructing social identities, such as differentiating Rockers from hip hop-inclined Cacos in subculture contexts (Ibid.). Contrasting these linguistic stylizations in U.S. and Puerto Rico, the living quality of language and communication becomes evident. In particular, communication patterns illustrate that the social meaning behind bilingual speech is reaccentuated or repurposed in each new context or instantiation, and, ultimately, intersubjectively constructed.

Michael Bakhtin's (1991) concept of heteroglossia is compatible with Silverstein's (2003) indexicality in that it emphasizes the dialogic nature of language. In Bakhtin's field of vision, there are no neutral words: language is the outcome of previous voices, uses, professions, social relations, and histories of languages - histories of power, solidarity, invasion, acts of acculturation and assimilation, resistance, policies and ideologies (BAKHTIN, 1981: 293). Bakhtin speaks of ideological 'tensions' manifested through what he calls centripetal and centrifugal forces: centripetal forces are "the pull towards uniformity" or standardization, centrifugal forces are "the pull towards difference" (normativity) (TAGG, 2016: 62). The centripetal and centrifugal forces are comparable to Silverstein's "macro" and "micro" distinctions, which operate under ideological forces based on hierarchy, or on indexical valorizations that are negotiated in interaction.

This paper unpacks the cultural journey Miguel must navigate in order to 'belong' on the island. This involves navigation of, firstly, the island's ideological norm or centripetal forces (i.e. the metapragmatic pulls of a collective Hispanic identity). Second, it involves a traverse of institutional norms, enforced by government, education institutes, and society (contextual presupposed knowledge). Third, Miguel must take into account the centrifugal forces of the locally emergent ways of speaking (as constructed dialogically). Through this passage, I demonstrate 
how Miguel stylistically draws on his indexical repertoire, composed of diverse structural and phonological styles, to construct his own social identity as both an authentic islander and an American teenager. I also adopt a stylistic approach to highlight the different varieties and styles within one ideologically constructed 'language'.

\section{METHODOLOGY}

The data discussed in this paper is drawn from a larger ethnographic study conducted in a private school in south-west Puerto Rico ${ }^{4}$. It is part of a Ph.D. project on youth language in public and private schools on the island. The excerpts are from a bilingual corpus collected over a six-month period, from September 2015 to March 20165. Language data was elicited through Labovian (1966) interview techniques. The Labovian sociolinguistic interview is designed to collect a sample of different speech styles, ranging from least formal to most formal. Rather than utilizing a fixed set of questions, questions were semi-structured - i.e. informed by emerging themes in the interview and locally relevant issues - such that the sample would mirror a naturally occurring conversation. The data was then uploaded and transcribed through use of standard orthographic conventions (first) and impressionistic phonological detail (second). Pseudonyms were employed in order to ensure youths right to privacy and confidentiality. Other sources of data not present in this study include field-notes, focus group interviews, and retrieval of community-specific artifacts (images, flyers, brochures, classroom handouts). Recurring discourse themes and language use were identified through several playbacks and coded for systematic analysis through a qualitative software package called NVIVO.

\section{THE CASE STUDY: MIGUEL}

Miguel was a 17-year-old male at Mission High, an elite private bilingual institution in Mayagüez. Throughout his childhood he lived in Virginia and Illinois, but spent most of his adolescence in Puerto Rico. He had ambitions of going back to the mainland, and joining his brother in Chicago to pursue a Bachelor's degree.

4. This Ph.D. project was supervised by Dr. Jeffrey Kallen (jkallen@tcd.ie) at Trinity College Dublin.

5. The transcripts that shape the discourse analysis of this paper are drawn from a 150,000-word corpus of bilingual speech elicited and transcribed by the author. 
His speech contained several varieties of English, including but not limited to AAVE, American Youth Speech, standardized American English, and Netspeak. His preferred conversational style was English, as suggested by Figures 1 and 2. Structurally, Miguel's speech was highly mixed in comparison to his peers, which leaned towards Spanish-dominant structures and occasional English constituents and lexical items (or borrowings). His style can be contextually interpreted as the outcome of his experiences as a transnational. However, as Tagg (2016) notes "individual repertoires shaped by personal life trajectories and social space need also to be understood as interactively emergent: co-constructed in the moment and continually re-shaped through identity positionings vis-à-vis interlocutors" (TAGG, 2016: 66).

Table 1. Miguel's dominant 'Language' per turn.

\begin{tabular}{|c|c|c|c|}
\hline \multicolumn{4}{|c|}{ Miguel's Bilingual Speech (Individual Interview: 0: 45: 00) } \\
\hline $\begin{array}{c}\text { English dominant } \\
\text { turns }\end{array}$ & Spanish dominant turns & Hybrid Turns & $\begin{array}{c}\text { TOTAL } \\
(\mathrm{N})\end{array}$ \\
\hline 122 & 17 & 4 & 143 \\
\hline
\end{tabular}

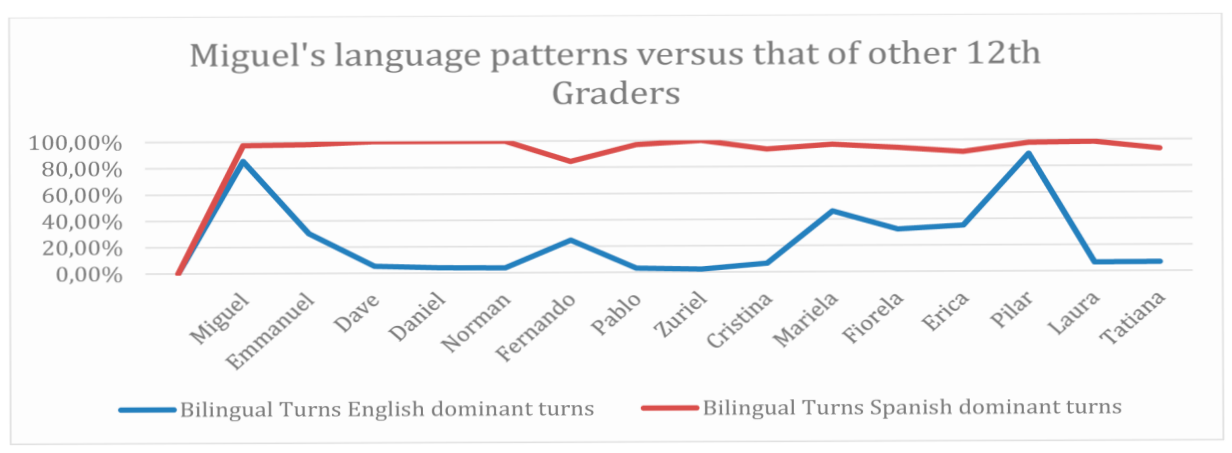

Figure 1.

*Note that other individuals in his school community engaged in high English turns: Notably Pilar and Mariela (both friends) and Fernando.

It should be noted that despite non-local practices, Miguel was accepted by his peers and held a desirable position in the social hierarchy as "one of the popular boys". In the discussion that follows, I demonstrate how Miguel maintained this desirable position within the language landscape of Puerto Rico, and everted the 
usual disregard of transnationals' "linguistic resources and values" (BLOMMAERT, 2007).

\section{STYLIZATIONS AND ACTS OF IDENTITY OF A PUERTO RICAN TRANSNATIONAL}

As a returnee, Miguel held non-local ties that placed him in a unique position when it came to linguistic affordances. As mentioned previously, Puerto Ricans have a well-defined notion of "Puerto Rican culture" or what it means to be an authentic islander. One of the cultural practices that authentic islanders are expected to demonstrate is the use of Puerto Rican Spanish in everyday social interactions. While it is not unusual to hear smaller instances of English use (e.g. loanwords), English-only utterances by an islander are typically frowned upon or deemed indicative of a White, European "other." This is articulated in the following way by Miguel's friend, Dave:

$($ Regular font $=$ PR Spanish $;$ Bold $=$ English $)$

\begin{tabular}{|c|c|}
\hline 1 Dave & 'There are people that that they get cocky - Tiffany! Tiffany! Well, and they get \\
\hline 2 & cocky and they believe they are gringo every \\
\hline 3 & now and then and they speak English all of the \\
\hline 4 & time.' (Interview Translation, October 2015). \\
\hline
\end{tabular}

Figura 2.

Miguel's linguistic style thus place him in an ideologically threatening position. By engaging in regional US Englishes in a Spanish-dominant setting he risks not being "one of us" (metapragmatic valorization) and consequently, "one of them" - a "gringo". However, while these metapragmatic discourses place him in an unfavorable position, Miguel is able to contest this meaning through strategic positioning acts, enabling him to reaccentuate what it means to speak English alongside Spanish in Puerto Rico.

\section{EXAMPLE 1. "WE (ARE) IN AMERICA": BLURRING GEOPOLITICAL BOUNDARIES AND NATIONAL IDEOLOGIES}

In the excerpt below, Miguel navigates and subtly subverts national ideologies that distinguish Puerto Rico from the United States. Within it, he relies 
on his presupposed knowledge, drawing on both Spanish and English (following the guidelines set down by the researcher from the study's outset), knowing that the researcher can understand his speaking style. He draws on his own experiences of transnationalism and travel to build common ground with the researcher, and demonstrates desire to continue this lifestyle in the future. Crucially, his is an act of ideological defiance. In the excerpt below Miguel contests the status quo and one-to-one correlational understandings of what it means to be Puerto Rican in Puerto Rico, as demonstrated in Lines 4 and 10. Through heteroglossic (bilingual) linguistic practices, Miguel constructs a persona that is "Murican": one that perceives Spanish and English, Anglo and Latino, and Puerto Rican and mainland American as constituting the same thing: "America".

Table 2. Example excerpt 'We (Are) in America'.

\begin{tabular}{|c|c|c|}
\hline Example 1. & Original & Translation \\
\hline 1 Miguel & Have you ever been to Turkey? Mi helmano fue y & 'My brother went and' \\
\hline 2 & todo eØ bien barato allá. & 'everything is very cheap there' \\
\hline 3 Katherine & I've never been, yo siempre he querido il. & \\
\hline 4 Miguel & Me too. I've never left 'Murica. & \\
\hline 5 Katherine & Pero, $<$ [he: 'lov] $>$, America is kind of cool. & 'But, hello!' \\
\hline 6 Miguel & America is great. Freedom! & \\
\hline 7 Katherine & ¿Tu quiereØ volvel? & 'Would you like to go back?' \\
\hline 8 Miguel & Pueh - to America? & 'Well -' \\
\hline 9 Katherine & Sí. & 'Yes' \\
\hline 10 Miguel & We in America, no? & \\
\hline 11 Katherine & wanna live in ... & \\
\hline 12 Miguel & Live in America... & \\
\hline 13 Katherine & Aja, ¿tú quiereØ vivir ahí? & 'Yeah, do you want to live there?' \\
\hline $\begin{array}{l}14 \text { Miguel } \\
15\end{array}$ & $\begin{array}{l}\text { I mean, I don't know, it depends, I think other } \\
\text { countries are nice, too. }\end{array}$ & \\
\hline
\end{tabular}

At the beginning of the interview, Miguel demonstrates interest in the researcher's background and travel experiences. To overcome his potential vulnerability as an interviewee, Miguel asks a question to the researcher in Line 1, thus switching the roles and yielding information from her. His speech is notably mixed in the first two lines, as he engages in inter-sentential stylizations of both standardized American English and Puerto Rican Spanish when he speaks of his brother's experiences travelling to Turkey (Lines 1 to 2). He refers to his own desires to explore new lands outside of his immediate reality in Line 4 when he aligns himself with the interviewer in wanting to visit Turkey, and he then makes use of emblematic item Murica (variant of "Merica") to refer to never having left 
the U.S. Here, he participates in contemporary Netspeak language and flaunts his status as American. 'Murica' is defined by Oxford Living Dictionaries as denoting informal 'nationalism'; it is also used in interaction as a way of expressing stereotypes of American behavior (OXFORD LIVING DICTIONARIES 2019, 'MERICA). Current Google searches yield over 5, 510, 000 results of this lexical item, most of which are related to social media and other networking sites, particularly in online meme and hashtag practices (e.g. Know Your Meme, YouTube, and Reddit). By appropriating the term 'Merica, Miguel temporarily positions himself as a legitimate American by drawing on popular media registers and their indexical valorizations. Simultaneously, he positions himself as a teenager literate in Internet popular culture distinguishing his speech "from the mainstream adult world" through nonstandard practices (BAILEY, 2012: 504).

In the exchange between Lines 5 and 6, Miguel participates in structural and ideological parallelism by responding to the researcher's evaluative statement, "America is kind of cool" (positive), to which he reacts enthusiastically with, "America is GREAT!" (extremely positive). In this way, he builds on the local voices of the micro and positions himself accordingly. Notably, "America" alongside "great" (Line 6) are ideologically infused lexical collocates, popularized in the 2016 U.S. last presidential campaign, but also found in other nationalistic discourses. Miguel's playful banter thus illustrates high-level metapragmatic awareness. In Line 12 , he engages in an act of shared intertextual knowledge and structural parallelism when he finishes the lyric to a song provided by the interviewer from the musical West Side Story: "(I want to) live in America." Through this "chiming in" or "joining in chorus" (TANNEN, 2007), Miguel jointly constructs (by researcher and interviewee) a vision of America as "a great place."

In Lines 8 and 10, Miguel hesitates in equating Puerto Rico as "elsewhere" in relation to America. In an act of defiance to the status quo (as well as to the researcher's own views) he challenges the researcher's question as well as macrosociological voices of Puerto Ricans as "different" or "disenfranchised" in African American Vernacular style: 'We in America, no?' (Line 10). Thus, he simultaneously showcases his transnational repertoire, gleaned from his contact with African Americans in the U.S. mainland (Cutler, 2008) ${ }^{6}$.

AAVE is seen as a style of resistance, giving voice to marginalized groups from urban minority backgrounds from all over the world (CUTLER, 2008). Miguel strategically uses this vernacular to construct an idea of the Latino race as

6. In his interview, Miguel makes use of AAVE features such as copula absence, lexical items such as Imma, and fixed expressions such as 'to be chill with (someone)' a total of 14 times. 
a legitimate part of the whole. In this sense, through translingual acts of identity and style, Miguel constructs a dynamic identity that challenges the oppressive logic of what it means to be Puerto Rican and Spanish-speaking in a segregated America, and towards the legitimization of Puerto Ricans as Americans. He further complicates the one-to-one binary values of Puerto Rican as necessarily Spanish speaking through his personal heteroglossic styles.

\section{EXAMPLE 2. OVER THERE VS. HERE: THE TRANSNATIONAL EXPERT}

In this part of the interview, Miguel takes on the role of a cultural expert, and positions himself as a local insider to both mainland and island culture. He refers to the emblematic traditions or practices that set each culture apart, ultimately indicating Miguel's metapragmatic and sociocultural competence of different values, beliefs, and behaviors and the contextual spaces they entail (BLOMMAERT, 2007) - his competence gained is a result of his transnational identity and experiences. His statements in Example 2 complicate his initial constructions of Puerto Rico "as one" or as part of America, by adding an element of difference that builds on the metapragmatic discourses of a separate Puerto Rican entity and cultural nationalism (DUANY, 2003).

Table 3. Example excerpt 'Aquí' versus 'Allá', straddling between cultural identities.

\begin{tabular}{|lll|}
\hline Example 2. & Original & Translation \\
\hline 30 Miguel & I remember a lot. I remember moments that & \\
31 & were important to me, I guess [...] & 'It's very pretty' \\
32 & Eh bien lindo, it's really awesome. And I used & \\
33 & to live, like, near this little forest, next to a river and me & \\
34 & and my friends used to make forts with the trees, survivor man, \\
35 & and stuff. We would go fishing, we would make our & \\
36 & own rods and stuff. I feel like the culture over there, is more - & \\
37 & they care more about like their children's imagination (.) & \\
38 & and tryina have, keep- make children keep their innocence, so & \\
39 & they can grow up with all that imagination stuff. Over & 'That's true.' \\
41 & here it's more like < [faemili]> and the holidayz. & \\
42 & Miguel & Over there is more like (.) the children, over here it's more \\
43 & like [faemili] and togetherness. Aunque allá eh & 'Although over there it's' \\
44 & togetherness también pero like it's like a different type of & 'also but' \\
45 & togetherness. Eh máh important, like, your emergent family. & 'It's more' \\
\hline
\end{tabular}


In lines 30 to 45 Miguel is recounting his experiences lived in Virginia, in an almost nostalgic tone, corroborated by repetition 'I remember', followed by an overt declaration of its importance and how it shaped who he is today. Visual elements involving nature and landscapes, as well as outdoor activities, are referenced in this excerpt from Lines 33 to 36. Collocates such as little forest, river, trees and fishing, are words that frequently co-occur among each other when referencing or constructing the persona of an outdoorsman or a 'survivor man (of the woods)' (Line 34) such that we get a sense of a particular iconic lifestyle or ritualization (Silverstein, 2003) - one that, within the context of Puerto Rico, is rare and thus indicative of his transnational status and sociocultural remittances or cultural knowledge earned elsewhere (NU ${ }^{N E Z, ~ 2019) . ~ H e ~ r e f e r e n c e s ~ a c t i o n s ~}$ that accompanied this lifestyle, such as building forts, gone fishing and 'make our own rods'(Lines 34 - 36), by referencing these behavioral practices of his past, Miguel displays himself as having lived a 'simple' and quintessentially 'rustic' American country life. Ultimately, he authenticates his identity as an American child by referencing imagery and practices of the countryside, often deemed 'pure' (untouched by civilization, industrialization, etc.) and 'real' America. He departs from his evaluation in Example 1, by describing these practices as unique to 'over there' (Line 36) and as an act of distinction equivalent to Puerto Rico's 'allá afuera', he positions himself favorably to that space. This distinction is revalidated through use of $3^{\text {rd }}$ person plural they (a collective distant populace) in Lines 36 to 39 , and their different ways of being and doing things to over here. In his definition of over there he refers to it being about the children and 'their imagination' after having described his own ideal practices as a child, once more positioning himself and his lived experiences in alignment with the practices over there. He uses 'over there' again this time in the local vernacular allá in Line 43, while he reconciles different practices by suggesting they both place an emphasis on the family, but in different manifestations: the island is more about "extended family" and the long Christmas holidays and family reunions (39 to 40), while over there is more about the immediate family and the children (Line 37, Line 39). In this sense, through narrative strategies and references to cultural rituals he positions himself as both an insider and expert to two communities and, simultaneously, a person of social prestige, capable of discerning the cultural difference between both.

Stylistically, Miguel uses comparative phrases such as "it's more" (Line 42) or "eh máh" (Line 45) and repetitive spatial referencing "allá" (Line 43) and "over there" (Line 36), thus demonstrating that it is not always the case that language/ style A is tied to meaning B. Rather, he infers that meaning is hybrid and does not 
necessitate ethnic-indexical correlations. It should be noted that Miguel navigates his story and positionalities (see BUCHOLTZ \& HALL, 2005) in standardized General American English, is in accordance to his linguistic upbringing or socialization (SCHIEFFELIN \& OCHS, 1986). "He also makes use of stylized teen speech features such as "all that...stuff" (Line 39) and "and stuff" (Lines 35, 36 ), referred to in the literature as general extenders or generic tag statements (see Tagliamonte, 2016). These occur alongside discourse tag "I guess". There is also a single instance of Puerto Rican Teen Talk in "pero like" / "but like" (Line 44), a collocation that has come into popular use over the past decade and was used several times in the bilingual corpus.

\section{EXAMPLE 3. "EN CASA ERA UN LEGIT LANGUAGE": ALIGNMENT TO THE LOCAL VERNACULAR AND ACTS OF AUTHENTIFICATION THROUGH SPANISHES}

Turning now to explicit evaluations of language competence, or metalinguistic comments, we can observe Miguel's construction of nationhood or of an authentic Puerto Rican by suggesting that he, too, owns Spanish and holds childhood memories of Spanish language. The excerpt below demonstrates his awareness of his own unusual mixed styles within the school and island landscape. Nonetheless, he insists that Spanish played a legitimate role in his family life and upbringing.

Table 4. Example excerpt "En casa eso era un legit language".

\begin{tabular}{|c|c|c|}
\hline \multicolumn{2}{|c|}{\begin{tabular}{|l|l|} 
Example 3. Original \\
\end{tabular}} & Translation \\
\hline 80 Katherine & ¿Y a ti: te enseñaron ehpañol cuando tu vivía $\emptyset$ allá? & \\
\hline 81 Miguel & I always knew it. & \\
\hline 82 Katherine & ¿Qué? & \\
\hline 83 Miguel & I always knew it. Que diga, quizáh no era perfect... & 'I mean, maybe it wasn't' \\
\hline 84 Katherine & Yeah, pero te lo hablaban= & \\
\hline 85 Miguel & [En casa eso era un legit language. & 'In our home that was a' \\
\hline 86 Katherine & ¿Cuál fue tu primer idioma? & \\
\hline 87 Miguel & I think I always spoke both, I mean obviously I speak better & \\
\hline 88 & English, than Ehpañol, but we always spoke both. It was always & 'Spanish' \\
\hline 89 & something in our house. & \\
\hline 90 Katherine & ¿Y tu- tu mamá? O sea, ¿cuál tu cree que ella:= & \\
\hline 91 Miguel & She's more fluent in Spanish, although she's lived i:n (.) loh & 'the' \\
\hline 92 & Ehtados Unido $\emptyset$ more, she was like her primary years of learning & \\
\hline 93 & where in Puerto Rico. & \\
\hline
\end{tabular}


Several iconic and indexical practices are taking place in this excerpt, as Miguel authenticates his 'island self' or Puerto Ricanhood to the researcher. First, we see this validation of Spanish competence through use of the intensifier "always." Miguel claims it was "always" something that he knew, indicating a type of cognitive possession, repeating the phrase "I always knew it" in Lines 81 and 84. In this instance, Miguel addresses the metapragmatic discourses that encourage societal Spanish monolingualism, by assuring that he too had this experience in his life. Significantly, "always" occurs a total of five times in this example, suggesting Miguel's need to ascertain his ownership of Spanish and lived experience as a Puerto Rican child. In this turn, he refers to Spanish through objectification, ascribing it as an "it" ( $3^{\text {rd }}$ person object). In Line 86, Miguel further authenticates his position as islander by using an idiomatic fixed expression from the local vernacular, "En casa eso era," a phrase that indicates a nostalgic anecdote of routine, "in our home that was..." followed by an instance of American youth slang, "un legit language"/ "a legit(imate) language", further hinting at the permanent and official role of Spanish in his home life, whilst simultaneously constructing his socialization experiences as "cool" or legit.

He later presents himself as an islander and owner of Spanish by referring to it in its local vernacular form "Ehpañol" (Line 89), thus positioning himself in alignment with the local community by engaging in a shared repertoire. This shared repertoire talks about the U.S. as not "America" but "loh Ehtados Unido Ø" , as evidenced in Line 93. "United States" serves as an official and distant form of address of the mainland, a proper noun, which Miguel stylistically draws on when narrating his mother's lived experiences as a Spanish-dominant speaker.

There is a hint of linguistic insecurity and acknowledgement of Miguel's non-local behaviors and how these violate wider island norms (but not school norms), when he says "Que diga, quizas no era perfect" (I mean, maybe it wasn't perfect) (Line 84) and in "Obviously I speak better English" (Lines 88 - 89) to talk about his translingual competence. In this sense, while Miguel understands the problematic nature of his English-dominant practices as deviating from the metapragmatic norm (see Figure 1 \& 2) and by using "not perfect", he simultaneously challenges one-to-one ideologies of the authentic islander as not owning the Spanish language and of being an 'outsider'. He demonstrates that he, too, is able to recall instances in which Spanish was the home language, and he uses peppered Puerto Rican Spanish to corroborate his account as a legitimate Spanish speaker. 


\section{DISCUSSION}

Throughout this article I have demonstrated how postcolonial transnationalism is achieved through a series of indexical moves that build on previous uses and ideologies of what it means to be transnational in Puerto Rico and have nonlocal practices (metapragmatics), knowledge of context-specific practices (presupposed knowledge), as well as locally built values that challenge the ideological norm as well as the presupposed. The choice of Miguel was strategic: he is not the representative Puerto Rican within the island contexts and his identity is not easily prescribed through a priori labels. Nevertheless, he is aware of the metapragmatic discourses of the United States' and that of the presence of the English language. Consequently, he navigates his own identity as a transnational through a series of indexical practices that point to different aspects of his own identity and the imaginative Spaces tied to those aspects:

\section{DE AQUÍ 'FROM HERE'}

- Through spatial distancing labels: allá, allá afuera, over there, eh 'It is' ( $3^{\text {rd }}$ person object), Ehtados UnidoØ (Proper Noun); as well as closeness labels 'over here', 'aquí', 'en casa'.

- Referencing family: 'the (big) family reunions' and 'the holidays' -hinting at sociocultural practices of Christmas alongside Epiphany (a Hispanic holiday tradition), also hinting at the 'big family' stereotypes of the quintessential Latino family.

- In Example 3, Miguel cements Spanish's role in his life through repeated use of adverb "Always", it was always a part of him.

\section{DE ALLÁ 'FROM THERE'}

- Referencing emblems of rural 'real' America: narrates memories of being outdoors, and activities that point to a 'simple life' and American childhood (Example 2): e.g. building forts, making their own fishing rods, etc.

- Use of nationalistic discourse: 'Murica, America 'is great!', and freedom.

\section{DE UNO 'FROM ONE'}

- In Example 1 Miguel blurs geopolitical boundaries and contests ideologies of separateness through the claim that he had always lived in America in Lines 4 and 10: "I have never left America", "We in America".

- Identifying cultural sameness: In Example 2, Miguel suggests that both cultures place an emphasis on the family and the children, though differently manifested. 
- Claiming ownership of both languages and memories of both cultures: "I always spoke both" (Line 88, Example 3); showcasing knowledge of cultural emblems of belonging (practices) (Example 2).

His acts of identity and belonging through specific language use and cultural references demonstrate that binary one-to-one correlations between language use and ethnic identity are problematic. Furthermore, shifts in language styles do not necessarily denote social meaning: instead, their indexical accumulation is what is socially meaningful. Miguel's conversational style is a performance of who he is as a transnational. His stylistic choices give him his social identity and he plays a full role in their selection. Through this account I have demonstrated how one person may draw on ideological values of what it means to speak a certain way to construct a new transcendent identity that is a cultural expert, complex, fluid, multivalent, both a local and an outsider. Ultimately, the way bilingual transnationals construct their identity is a personal, individual matter, that builds previous uses and voices, and orients to current voices dialogically in order to accomplish meaning in interaction.

\section{REFERENCES}

ALIM, H.S., IBRAHIM, A., \& PENNYCOOK, A. (2009). Global linguistic flows: Hip Hop Cultures, Youth Identities, and the Politics of Language. London \& New York: Routledge.

BAKHTIN, M. (1981). The Dialogic Imagination: Four Essays. Austin, TX: University of Texas Press.

BASCH, L., GLICK SCHILLER, N., \& SZANTON, C. (2005). Nations unbound: Transnational projects, postcolonial predicaments, and deterritorialized nationstates. Routledge.

BAUBOCK, R., \& FAIST, T. (2009). Diaspora and Transnationalism: Concepts, Theories and Methods. Amsterdam University Press.

BLACKLEDGE, A., \& CREESE, A. (2015). "Emblems of identities in four European urban settings." In Nortier and Svendsen's (eds.) Language, Youth, and Identity in the $21^{\text {st }}$ Century. Cambridge University Press.

BLOMMAERT, J. (2010). The Sociolinguistics of Globalization. Cambridge, UK: Cambridge University Press. 
BLOMMAERT, J. (2007). Sociolinguistic scales. Intercultural Pragmatics, 4 (1).

BRIGGS, L., MCCORMICK, G., \& WAY, J. T. (2008). Transnationalism: A category of analysis. American Quarterly, 60(3), 625-648.

BUCHOLTZ, M., \& HALL, K. (2005). Identity and interaction: A sociocultural linguistic approach. Discourse studies, 7 (4-5), $585-614$.

BURNETT, C. D., MARSHALL, B., JOSEPH, G. M., ROSENBERG, E. S. (2001). Foreign in a Domestic Sense: Puerto Rico, American Expansion, and the Constitution. Duke University Press.

CUTLER, C. (2008). "Keepin' it Real": White Hip-Hoppers' Discourses of Language, Race, and Authenticity. Journal of Linguistic Anthropology, 13 (2).

DE FINA, A., PERRINO, S. (2013). Transnational Identities. Applied Linguistics, 34 (5), pp. 509-515.

DeSIPIO, L., \& PANTOJA, A. D. (2007). Puerto Rican Exceptionalism? A Comparative Analysis of Puerto Rican, Mexican, Salvadoran, and Dominican Transnational Civic and Political Ties. In R. Espino, D.L. Leal, \& K.J. Meier Latino Politics: Identity, Mobilization, and Representation. University of Virginia Press.

DUANY, J. (2003). Nation, migration, identity: The case of Puerto Ricans. Latino Studies, 1 , pp. 424-444.

DUFF, P. A. (2015). Transnationalism, Multilingualism, and Identity. Annual Review of Applied Linguistics, 35, pp. 57-80.

ECKERT, P., \& MCCONNELL-GINET, S. (1992). Think practically and look locally: Language and gender as community-based practice. Annual review of anthropology, $2(1)$, p. 461-488.

GAL, S. (2006). Migration, minorities and multilingualism: Language ideologies in Europe. In Language ideologies, policies and practices (pp. 13-27). Palgrave Macmillan, London.

GARDINER, M. (2002). The Dialogics of Critique: M.M. Bakhtin and the Theory of Ideology. Routledge. 
GARCÉS-CONEJOS BLITVICH, P. (2018). Globalization, transnational identities, and conflict talk: The superdiversity and complexity of the Latino identity. Journal of Pragmatics, 134, pp. 120-133.

HOLQUIST, M. (2002). Dialogism: Bakhtin and His World. Routledge.

LEVITT, P., \& JAWORSKY, B.N. (2007). Transnational Migration Studies: Past Developments and Future Trends. Annual Review of Anthropology, 33, pp. 129156.

LIPSKI, J. M. (2008). Varieties of Spanish in the United States. Georgetown University Press.

MACHADO-CASAS, M. (2012). Pedagogías del Cameleón: Identity and Strategies of Survival for Transnational Indigenous Latino Immigrants in the US South. The Urban Review, 44 (5), pp. 534-550.

MAZAK, C. M., CARROLL, K. S. (Eds.). (2016). Translanguaging in higher education: Beyond monolingual ideologies. Multilingual Matters.

MELÉNDEZ, E. (2015). Puerto Rican Migration, the Colonial State, and Transnationalism. Centro Journal, XXVII (II), pp. 50-95.

MENDOZA-DENTON, N. (1999). Sociolinguistics and Linguistic Anthropology of US Latinos. Annual Review of Anthropology, 28, pp. 375 -395.

MORALES, K. R. (Forthcoming). Reimaging Bilingualism in Late Modern Puerto Rico. In J. Won Lee \& S. Dovchin (Eds.) Translinguistics: Negotiating Innovation and Ordinariness. Routledge.

PÉREZ CASAS, M. (2008). Codeswitching and identity among island Puerto Rican bilinguals (Doctoral dissertation, Georgetown University).

PEW RESEARCH CENTER. (2017). Key findings about Puerto Rico. [Online]. Available at: http://pewresearch.org/fact-tank/2017/03/29/key-findings-about-puerto-rico.

PORTES, A., GUARNIZO, L. E., \& LANDOLT, P. (1999). The study of transnationalism: pitfalls and promise of an emergent research field. Ethnic and racial studies, 22 (2), pp. 217-237.

POUSADA, A. (1999). The singularly strange story of English in Puerto Rico. Milenio, 3, 33-61. 
POUSADA, A. (2007). The sociolinguistic implications of teaching English in Puerto Rico. PRTESOL-Gram, 33 (3), pp. 6-27.

ROSA, J. D. (2016). Standardization, Racialization, Languagelessness: Raciolinguistic Ideologies across Communicative Contexts. Journal of Linguistic Anthropology.

SÁNCHEZ, P., \& MACHADO-CASAS, M. (2009). At the Intersection of Transnationalism, Latina/o Immigrants, and Education. The High School Journal, 92 (4), pp. 3-15.

SCHIEFFELIN, B. B., \& OCHS, E. (1986). Language socialization across cultures. Cambridge University Press.

SILVERSTEIN, M. (2003). Indexical order and the dialectics of sociolinguistic life. Language \& Communication, 23, pp. 193-229.

TAGG, C. (2016). Heteroglossia in text-messaging: Performing identity and negotiating relationships in a digital space. Journal of Sociolinguistics, 20 (1), pp. 59-85.

TAGLIAMONTE, S. (2016). Teen Talk: The language of adolescents. Cambridge University Press.

TANNEN, D. (2007). Talking voices: Repetition, dialogue, and imagery in conversational discourse (Vol. 26). Cambridge University Press.

U. S. CENSUS BUREAU (2018). Annual Estimates of the Resident Population: April 1, 2010 to July 1, 2018. Retrieved from: https://factfinder.census.gov/faces/nav/jsf/ pages/community_facts.xhtml? src $=$ bkmk

VERVOTEC, S. (2007). Super-diversity and its implications. Ethnic and racial studies, 30 (6), pp. 1024-1054. 


\section{APPENDIX}

Table 5. Transcription conventions (adopted from SACKS ET AL., 1974; MASON, 2011).

\begin{tabular}{|c|c|}
\hline$(-)$ & $\begin{array}{l}\text { a dash marks a sudden cut-off of the current sound or word, by the } \\
\text { speaker himself as a way to repair or rephrase his/her utterance. }\end{array}$ \\
\hline$<[]>$ & $\begin{array}{l}\text { is used to indicated phonetic transcription, only used when } \\
\text { sociolinguistically significant, particularly to voice quality or } \\
\text { tonality. }\end{array}$ \\
\hline$(=)$ & cut-off (dialogue): to signal an interruption by another speaker. \\
\hline[ & To signal overlapping speech in dialogue. \\
\hline \multirow{2}{*}{\multicolumn{2}{|c|}{$\begin{array}{l}\text { Translation is indicated by 'quoted commentary' } \\
\text { Intonation }\end{array}$}} \\
\hline & \\
\hline (.) & Period indicates falling contour \\
\hline$(?)$ & Indicates a rising contour. \\
\hline$($ (,) & Indicates a fall-rise contour. \\
\hline$(())$ & Comments italicized with double parenthesis. \\
\hline $\begin{array}{l}\text { Silence \& } \\
\text { Pauses }\end{array}$ & $\begin{array}{l}\text { numbers in parentheses mark silences in seconds and tenths of } \\
\text { seconds greater than three seconds. Pauses under the seconds are } \\
\text { indicated by the respective number (.) dots. }\end{array}$ \\
\hline \multicolumn{2}{|l|}{ Sounds } \\
\hline (h) & Aspiration in Puerto Rican Spanish. \\
\hline$\varnothing$ & Omission of sound. \\
\hline
\end{tabular}

Recebido: $17 / 12 / 2018$

Aceito: 10/03/2019

Publicado: 29/03/2019 